\title{
EFEKTÍVNE ÚSTAVNÉ SÚDNICTVO AKO ÚSTAVOU CHRÁNENÁ HODNOTA
}

\section{EFFECTIVE CONSTITUTINAL JUDICIARY AS VALUE PROTECTED BY CONSTITUTION}

\author{
Ladislav Orosz \\ Univerzita Pavla Jozefa Šafárika v Košiciach, Právnická fakulta \\ https://doi.org/10.33542/SIC2019-1-01
}

\begin{abstract}
ABSTRAKT
Efektivvna súdna kontrola ústavnosti je jednou z klúčových charakteristík demokratického a právneho štátu a poživa ústavnú ochranu. Úlohou všetkých orgánov verejnej moci je preto v rámci svojej pôsobnosti zabezpečovanie funkčného ústavného súdnictva. Autor vo všeobecnej rovine vymedzuje, kedy možno súdnu kontrolu ústavnosti za efektívnu a pomenúva klúčové faktory, ktoré ju podmieňujú. Na tomto základe autor podrobuje kritickej analýze platnú ústavnú a zákonnú úpravu, ktorá tvorí právny základ činnosti Ústavného súdu Slovenskej republiky a formuluje námety na jej skvalitnenie.
\end{abstract}

\begin{abstract}
ABSRTRACT
Effective constitutional judiciary is one of the key characteristics of democratic state governed by the rule of law that enjoys constitutional protection. Thus, all public authorities are assigned to ensure functional constitutional judiciary. The author defines in general way effective judicial review of constitutionality and sets out the key factors that underlie such review. On above mentioned basis the author critically analyses valid constitutional and legal regulations of functioning of Constitutional Court of Slovak Republic and forms proposals for improvement of such regulation.
\end{abstract}

\section{I. ÚVOD}

Jednou z kl'účových konštrukčných súčastí moderného konštitucionalizmu je celkom nepochybne idea súdnej kontroly ústavnosti, ktorá sa aj bez ústavnej fixácie na americkom kontinente premietla do ústavnej praxe začiatkom 19. storočia prostredníctvom jedného z najvýznamnejších rozhodnutí Najvyššieho súdu USA vo veci Marbury v. Madison z roku 1803. ${ }^{1}$ Aj ked' idea súdnej kontroly ústavnosti sa kontinuálne formovala aj na európskom kontinente, k jej reálnemu presadeniu do ústavnej praxe došlo až po skončení I. svetovej vojny. Ciel'om tejto štúdie nie je analyzovat' podrobnejšie príčiny európskeho omeškávania, ktoré boli v materských krajinách európskeho konštitucionalizmu Francúzsku a Vel'kej Británii objektívne historicky podmienené dominantnou úlohou parlamentu pri presadzovaní revoluč-

\footnotetext{
Analytický rozbor slávneho rozhodnutia amerického najvyššieho súdu je predmetom mnohých vedeckých štúdií a odborných publikácií, z ktorých sa spravidla za najviac autoritatívnu považuje analýza podaná v diele prof. Corwina; Lectures on the Constitution of the United States. Boston 1939, s 414 a nasl..
} 
ných zmien (Francúzsko) ${ }^{2}$, resp. dlhodobo formovanou britskou ústavnou doktrínou suverenity parlamentu (Vel'ká Británia). ${ }^{3}$

Zjavne najústretovejší prístup $\mathrm{k}$ myšlienke súdnej kontroly ústavnosti tak $\mathrm{v}$ ústavnoteoretickej ${ }^{4}$, ako aj $\mathrm{v}$ ústavno-praktickej rovine panoval v prvej polovici 20. storočia v strednej Európe. Zostane historickým faktom, že európsky model súdnej kontroly ústavnosti, ktorého nositel’om je špecializovaný súdny orgán (spravidla označovaný ako ústavný súd) sa v teoretickej rovine sformoval vd'aka predstavitel'om tzv. normatívnej právnej školy Hansa Kelsena na začiatku 20. storočia na území Rakúsko - Uhorska a do ústavnej roviny bol prvýkrát premietnutý v Česko-Slovensku prostredníctvom zákona č. 121/1920 Sb. z 29. februára 1920, ktorým sa uvádza ústavná listina Československej republiky. ${ }^{5}$ Zásadný prielom súdnej kontroly ústavnosti do ústavnej praxe $\mathrm{v}$ európskom priestore možno ale registrovat' až po II. svetovej vojne a to predovšetkým vd’aka Základnému zákonu SRN a z roku 1949 a na jeho základe konštituovanému Spolkovému ústavnému súdu SRN, s ktorého rozhodovacou činnost'ou je nerozlučne spätý prechod od formalistického chápania kontroly ústavnosti, k materiálnemu chápaniu súdnej kontroly ústavnosti.

Na prelome tisícročí je súdna kontrola ústavnosti integrálnou súčast’ou ústavných systémov $v$ zásade všetkých recentných demokratických a právnych štátov a to bez ohl'adu na model, ktorý sa $\mathbf{v}$ nich uplatňuje. ${ }^{6} \mathrm{~K}$ výraznému rozšíreniu a posilneniu súdnej kontroly ústavnosti došlo $\mathrm{v}$ európskom priestore po mocenských zmenách $\mathrm{v}$ bývalých socialistických štátoch, ktoré boli ústavne fixované $\mathrm{v}$ ich nových ústavách pochádzajúcich najmä z prvej polovici 90 -tych rokov minulého storočia. ${ }^{7} \mathrm{Z}$ analýzy platných ústav týchto štátov možno vyvodit', že jedným z ich esenciálnych charakteristických znakov je konštituovanie, resp. renesancia ústavného súdnictva ${ }^{8}$. Zároveň sa žiada poznamenat', že ústavné súdy konštituované $\mathrm{v}$ týchto štátoch boli, aj v porovnaní s tradičnými európskymi demokraciami, vybavené vo väčšine prípadov s vel'mi širokým rozsahom kompetencií, ktoré vytvorili a vytvárajú ús-

2 K vývoju názorov na kontrolu ústavnosti vo Francúzsku pozri z všeobecne dostupnej literatúry napr. KLOKOČKA, V.: Ústavní zř́zení evropských států. Praha Linde 1996, s. 378 a nasl., tiež OROSZ, L.: O preventivnej kontrole ústavnosti. Právny obzor, 89, 2006, č. 6., s. 487 a nasl., a z ostatného obdobia najmä GIBA, M.: Súdna kontrola ústavnosti vo Francúzsku. Bratislava: Wolters Kluwer, s.r.o., 2017, s. 18 a nasl.

3 Z klasických diel britskej konštitucionalistiky k tomu pozri napr. DICEY, A.V.: Introduction to the Study of the Law of the Constitution. London, 1927, s. 60 a nasl., alebo Lord LESTER of Herne Hill - OLIVER, Dawn. (ed).: Constitutional and Human Rights. London, 1997, s. 7 a nasl..

$4 \mathrm{Ku}$ kryštalizácii doktrinálnych názorov na súdnu kontrolu ústavnosti v európskom priestore podrobnejšie pozri napr. MLSNA, P.: Ústavni soudníctvi ve státovédnem mysleni. Právnik, 2009, č. 10, s. 1021 - 1029.

5 Česko-Slovensku nepochybne patrí historické prvenstvo z hl’adiska ústavného zakotvenia špecializovaného súdneho orgánu kontroly ústavnosti, ale už nie z hl'adiska začiatku jeho reálneho fungovania. V čase, ked' sa prvýkrát Ústavný súd Československej republiky zišiel na svojom zasadnutí (17. júna 1921) už totiž niekol'ko mesiacov pôsobil viedenský Verfassugsgerichtshof, zriadený podl'a rakúskej spolkovej ústavy z 1. októbra 1920 (k tomu viac LANGÁŠEK, T.: Ústavni soud Československé republiky a jeho osudy v letech 1920 - 1948. Plzeň: Aleš Čeněk, s.r.o., s. 15 a nasl.

$6 \quad$ V odbornej literatúre sa v zásade rozlišujú dva základné modely súdnej kontroly ústavnosti a) všeobecný model súdnej kontroly ústavnosti, v rámci ktorého súdnu kontrolu ústavnosti vykonávajú všeobecné súdy, b) špecializovaný a koncentrovaný model súdnej kontroly ústavnosti, v ktorom vykonáva súdnu kontrolu ústavnosti špecializovaný orgán súdneho typu, spravidla označovaný ako ústavný súd. Na základe tohto základného členenia možno potom rozlišovat' d’alšie typy (podtypy) súdnej kontroly ústavnosti. K tomu viac pozri v slovenskom prostredí všeobecne akceptovanú klasifikáciu obsiahnutú v diele renomovaného českého špecialistu na problematiku súdnej kontroly ústavnosti doc. JUDr. Jana Blahoža, DrSc. (BLAHOŽ, J.: Soudni kontrola ústavnosti. Srovnávaci prehled. Praha: ASPI Publisching, s.r.o., 2001, s. 67 a nasl.).

7 Viac o týchto ústavách pozri napr. OROSZ, L.: Ústavy štátov strednej a východnej Európy (pokus o všeobecnú charakteristiku).Právnik, roč. 148, č. 11,3009, s. 1148 - 1157.

8 Prakticky vo všetkých štátoch bývalého „východného bloku“ boli v transformačnom období zriadené ústavné súdy. Výnimku predstavuje Estónsko (tu vykonáva dozor nad ústavnost’ou právnych predpisov nižšej právnej sily monokratický orgán Kancelár spravodlivosti, ktorý má právo predložit’ návrh na zrušenie protiústavných aktov Štátnemu súdu) a z post sovietskych republík ešte aj Turkmenistan. K ústavnému súdnictvu v štátoch strednej a východnej Európy podrobnejšie pozri napr. GRANAT, M.: Sadova kontrola konstytucyjności prawa w państwach Europy Środkowej $i$ Wschodniej Warszawa: Wydawnictwo Sejmowe, 2003, alebo SUCHÁNEK, R.: Ústavni soudnictví ve státech střední a východni Evropy. In.: PAVLÍČEK, V. a kol.: Transformace ústavnich systémů zemi středni a východni Evropy. I. část. Praha: Univerzita Karlova, 1999, s. $50-87$. 
tavné predpoklady na rast ich autority a silné postavenie $v$ ústavnom mechanizme, čo zvlášt' platí o štátoch tzv. Vyšehradskej štvorky rozprestierajúcich sa z vel'kej časti na teritóriu, ktoré možno považovat' za „kolísku“ zrodu špecializovanej formy súdnej kontroly ústavnosti.

Silné ústavné postavenie ústavných súdov vo väčšine súčasných demokratických štátov zjavne signalizuje, že ústavné súdnictvo na prelome tisícročí už netvorí len ozdobnú fasádu ústavno-politického mechanizmu, ale mimoriadne dôležitú súčast' ústavnopolitického inštrumentária moderného demokratického a právneho štátu, ktorého hlavnou funkciou je ochranu l'udských práv a základných slobôd a súdna kontrola ústavnosti (v niektorých špecifických oblastiach nie zriedka aj kontrola zákonnosti) výkonu verejnej moci všetkými ostatnými orgánmi verejnej moci. Pre väčšinu recentných demokratických a právnych štátov je tak $\mathrm{v}$ ostatných desat'ročiach charakteristický nebývalý (nominálne právny, ale i faktický) nárast moci ústavných súdov, ktorý ale má svoje limity a úskalia, ${ }^{9}$ čo možno v ostatnom období zretel'ne ilustrovat' na celom rade ústavne relevantných sporov, ako aj emotívne (skôr politicky, ako odborne) ladených diskusií, ktoré vznikli v okolitých krajinách (v ostatnom období zvlášt’ v Pol'sku, ale aj v Chorvátsku, Slovenskej republike, nedávno tiež v Mad'arsku, ako aj v Českej republike) súvisiacich s kreovaním personálneho zloženia ústavných súdov, snahami o precizovanie ich právneho postavenia, rozširovaním, či naopak obmedzovaním ich kompetencií, ako aj kritickou analýzou praktických dopadov ich rozhodovacej činnosti na fungovanie ústavného mechanizmu. Žial' nie sú ojedinelé aj prípady, ked' zákonodarca (v prípade Mad'arska aj ústavodarca) bezprostredne reagujúc na súdny aktivizmus ústavného súdu súvisiaci s plnením jeho klúčovej ústavnej funkcie (ochrany ústavnosti) legislatívnymi opatreniami obmedzil jeho pôsobnost', zmenil podmienky kreovania personálnej zostavy súdu, skomplikoval jeho uznášaniaschopnost', či inak st’ažil jeho funkčnost'.

\section{PREDSTAVA ÚSTAVODARCU O EFEKTÍVNOM ÚSTAVNOM SÚDNICTVE AKO ÚSTAVOU CHRÁNENÁ HODNOTA}

Ak budeme vychádzat' z premisy, že ústavná fixácia právneho postavenia ústavných súdov, ako špecializovaných súdnych orgánov kontroly ústavnosti, minimálne v stredoeurópskom priestore zodpovedá úlohám, ktoré by ústavné súdy mali plnit' v podmienkach súčasného demokratického a právneho štátu, tak sa aj v nadväznosti na už načrtnuté idey, javí kl'účovým problémom zabezpečenie efektívnosti (efektívnosti pôsobenia) ústavného súdnictva $\mathbf{v}$ tom ktorom štáte. Význam efektívneho ústavného súdnictva opakovane pripomína vo svojich dokumentoch Európska komisia pre demokraciu prostredníctvom práva (tzv. Benátska komisia) konštatujúc, že „Ústavné súdnictvo je klúčovou zložkou bŕzd a protiváh v ústavnej demokracii"“10 a zároveň akcentujúc (v aplikácii na Pol'sko, ale nepochybne so všeobecnou platnost'ou, pozn.), že „Ochromenie efektivity Ústavného tribunálu podkopáva všetky tri základné princípy Rady Európy: demokraciu (pretože bude chýbat' nevyhnutná čast' bŕzd a protiváh), l'udské práva (pretože by sa mohol spomalit' prístup jednotlivcov $k$ Ústavnému tribunálu na takú úroveň, že by to malo za dôsledok odopretie spravodlivosti) a právny štát (pretože ústavný tribunál, ktorý je ústrednou častou pol’ského súdnictva, sa stane neefektívnym ....". ${ }^{11}$ Na požiadavku efektívneho pôsobenia súdnej kontroly ústavnosti poukázala Benátska komisia aj v Stanovisku k otázkam týkajúcim sa menovania sudcov

\footnotetext{
9 O tom viac OROSZ, L.: Rast moci ústavných súdov - limity a úskalia. In.: JERMANOVÁ, H. - MASOPUST, Z. (eds.).: Metamorfózy práva ve strédní Evropě. Praha: Ústav státu a práva, 2008, s. 191 - 205.

10 Stanovisko k štvrtej novele Základného zákona Mad'arska, prijaté Benátskou komisiou na jej 95. plenárnom zasadnutí, 14.-15.júna 2013, CDL-AD (2013)012, bod 76; obdobne, Stanovisko k novele organického zákona o ústavnom súde a k novele zákona o konaní pred ústavným súdom, prijaté Benátskou komisiou na jej 107. plenárnom zasadnutí, 10.-11. júna 2016, CDL-AD (2016)017, bod 10 (týkajúce sa Gruzínska).

11 Stanovisko k novele zákona o Ústavnom tribunáli Pol’skej republiky z 25. júna 2015, prijaté Benátskou komisiou na jej 106. plenárnom zasadnutí, 11.-12. marca 2016, CDL-AD(2016)010, bod 137.
} 
Ústavného súdu Slovenskej republike CDL-AD (2017)001 č. 877/2017 z 13. marca 2017, (d’alej aj „Stanovisko k menovaniu sudcov ústavného súdu“), v ktorého bode 43 sa zdôrazňuje, že „,nepretržité fungovanie ústavného súdu ako konečného arbitra v ústavnoprávnych otázkach je mimoriadne dôležité pre demokraciu, ochranu l'udských práv a právny štát."

Jednou z dominantných obsahových súčastí každej ústavy je ustanovenie mechanizmu organizácie a fungovania verejnej moci, ktorého integrálnou súčast'ou (zvlášt' v podmienkach recentného demokratického a právneho štátu) je aj fixácia mechanizmov del'by moci a systém vzájomných bŕzd a protiváh. Ak $\mathbf{v}$ tomto mechanizme demokratický ústavodarca prizná zásadný význam ústavnému súdu, ako súdnemu orgánu kontroly ústavnosti, tak to nerobí samoúčelne, ale so zjavným zámerom reálne premietnut' tento kontrolný mechanizmus do ústavno-politickej praxe. $Z$ nadradeného postavenia ústavodarnej moci, ako priameho nositel'a vôle suveréna, vo vzt'ahu k všetkým ostatným štátnym (verejným) mociam $^{12}$ pôsobiacim na teritóriu štátu, možno vyvodit' povinnost' všetkých odvodených mocí (zákonodarnej, výkonnej i súdnej) orientovat' svoje právne relevantné aktivity $\mathrm{k}$ tomu, aby sa predstava ústavodarcu o fungovaní mechanizmov demokratického a právneho štátu $\mathrm{v}$ ústavno-politickej praxi maximálnym spôsobom realizovala. V načrtnutom kontexte ústavou fixovaná predstava ústavodarcu o efektívnom ústavnom súdnictve predstavuje významnú spoločenskú hodnotu, ktorej ochrana má charakter pozitívneho záväzku štátu zaväzujúceho všetky ostatné zložky štátneho mechanizmu. Vzhl'adom na funkcie, ktoré plnia ústavné súdy v mechanizmoch fungovania demokratického a právneho štátu, treba funkčné a teda efektívne ústavné súdnictvo považovat' za ústavou chránenú hodnotu, ktorú by mali chránit' a zvel'ad'ovat' všetky orgány verejnej moci.

Klúčovým ciel'om tejto štúdie je poukázat' na to, ako sa darí uvedený záväzok napĺn̆at' v podmienkach Slovenskej republiky, k čomu ma motivuje nielen situácia na Ústavnom súde Slovenskej republiky v ostatnom období (dlhodobé pôsobenie v nekompletnom zložení a s tým súvisiaca neprimeraná zat'aženost' jeho sudcov priamo podmieňujúca kvalitu rozhodovacej činnosti) ${ }^{13}$, ale aj skutočnost', že Československo, ktorého integrálnou súčast’ou bolo Slovensko v období rokov 1918 až 1992, predstavuje v historickom exkurze priam učebnicový príklad nefunkčného ústavného súdnictva.

Ak budeme na jednej strane považovat' za zrod súdnej kontroly ústavnosti na teritóriu dnešnej Slovenskej republiky 29. február 1920, t.j. deň schválenia ústavnej listiny Československej republiky, ktorá ústavne fixovala Ústavný súd Československej republiky ako špecializovaný orgán súdnej kontroly ústavnosti, tak možno zdôraznit', že ústavné súdnictvo sa na našom území už dožilo ,úctyhodného veku“, ktorý v európskom priestore v zásade nemá paralelu (s výnimkou Rakúska). Zároveň však treba jedným dychom dodat', že v rámci tohto dnes už takmer storočného obdobia prevažovali obdobia, ked' ústavné súdnictvo bud' vôbec nebolo ústavne fixované (obdobie rokov 1948 - 1968) ${ }^{14}$, alebo existovalo len „na papieri“ (obdobie rokov 1931 - 1938, ${ }^{15}$ tiež obdobie rokov $1939-1945^{16}$, a následne aj obdobie 1945

12 O tom viac OROSZ, L. - SVÁK, J. - BALOG, B.: Základy teórie konštitucionalizmu. 2. vydanie. Bratislava: EUROKÓDEX, 2012, s. 17 a nasl.

13 K tomu pozri napr. analytické dokumenty Ochrana ústavnosti a Ústavy Slovenskej republiky v rozhodovacej činnosti Ústavného súdu Slovenskej republiky za rok 2016, s. 7 a nasl. a Ochrana ústavnosti a Ústavy Slovenskej republiky v rozhodovacej činnosti Ústavného súdu Slovenskej republiky za rok 2017, s. 13 a nasl Dostupné na internete: https://www.ustavnysud.sk/ochrana-ustavnosti.

14 Obdobie socialistického Československa, v ktorom prevládajúca ústavná doktrína vylučovala existenciu súdneho orgánu kontroly ústavnosti, ktorý by mohol vykonávat' kontrolu občanmi priamo voleného a občanmi kontrolovaného najvyššieho zastupitel'ského zboru.

15 Obdobie tzv. „intermezza“, ked’ československý ústavný súd síce nebol zrušený, ale nebol personálne obsadený a teda bol nefunkčný. K tomu viac napr. LANGÁŠEK, T.: op. cit. d., s. 125 - 144

16 Obdobie tzv. slovenského štátu, v ktorého základnom zákone (ústavný zákon č. 185 Sl. zák. z 21. júla 1939 o Ústave Slovenskej republiky) síce bol zakotvený osobitný súdny orgán - Ústavný senát, ktorý mal podl’a predstáv ústavodarcu, ako aj predstáv premietnutých do vykonávacieho ústavného zákona č. 20/1942 Sl. zák. o Ústavnom senáte vykonávat' súdnu kontrolu ústavnosti, ale tento orgán v skutočnosti nikdy nebol ustanovený. 
- $1948^{17}$ a osobitne obdobie $1968-1991^{18}$ ), pričom ani tie ústavné súdy, ktoré určitý čas „fungovali“ nezohrali, resp. nemohli zohrat', vzhl'adom na obmedzený rozsah svojich kompetencií (Ústavný súd Československej republiky v rokoch 1921 - 1931), resp. obmedzenú dížku svojho fungovania (Ústavný súd ČSFR, ktorý pôsobil len v roku 1992 - necelých desat' mesiacov), významnejšiu úlohu v ústavno-politickom systéme, čo výstižne vyjadril podpredseda posledného federálneho ústavného súdu Vlastimil Ševčík „.. ani jednému z ústavných súdov nebolo dopriate zasiahnut' do ústavnosti štátu a položit' základy tradície pre ústavné

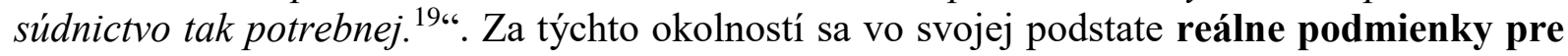
efektívne fungujúce ústavné súdnictvo v Slovenskej republike vytvorili až po schválení Ústavy Slovenskej republiky, na základe ktorej sa konštituoval Ústavný súd Slovenskej republiky s mimoriadne širokým rozsahom právomocí. Aj ked' možno prvé štvrt'storočie jeho fungovania hodnotit' $\mathrm{v}$ zásade pozitívne, $\mathrm{v}$ ostatných rokoch sa $\mathrm{v}$ dôsledku viacerých synergicky pôsobiacich faktorov jeho funkčnost' nie nezanedbatel'ným spôsobom naštrbila, a preto je potrebné tejto problematike venovat' zvýšenú pozornost'.

\section{FAKTORY PODMIEŇUJÚCE EFEKTÍVNOSŤ SÚDNEJ KONTROLY ÚSTAV- NOSTI}

Ešte pred analýzou niektorých aktuálnych problémov, ktoré potenciálne môžu ohrozit' funkčnost' Ústavného súdu Slovenskej republiky sa žiada v teoretickej rovine načrtnút', za akých okolností možno považovat' ústavné súdnictvo za efektívne a zároveň tiež pomenovat' kl'účové faktory, ktoré podmieňujú efektívnost' súdnej kontroly ústavnosti. $\mathrm{Za}$ efektívnu možno súdnu kontrolu ústavnosti podl'a môjho názoru považovat' predovšetkým vtedy, ak

a) je súdny orgán kontroly ústavnosti vybavený takými právomocami, ktoré mu umožňujú účinne plnit’ funkciu ústavného garanta ochrany l’udských práv a základných slobôd, ako aj funkciu ústavného garanta ústavnosti výkonu verejnej moci,

b) je zároveň ústavný súd (personálne, materiálne i organizačne) spôsobilý uplatňovat' svoje právomoci tak, aby ochranu ústavou chránených hodnôt poskytoval v požadovanej kvalite a v primeranom čase.

V rámci faktorov, ktoré podmieňujú efektívnost' výkonu súdnej kontroly ústavnosti treba podl'a môjho názoru rozlišovat' medzi vnútornými a vonkajšími faktormi. Za vnútorné faktory podmieňujúce efektívnost' výkonu ústavného súdnictva, považujem pritom tie, ktorých pôsobenie je závislé od samotného ústavného súdu, resp. také, ktorých pôsobenie je vo vlastnej réžii spôsobilý ovplyvnit’ predovšetkým samotný ústavný súd a to v prvom rade kvalitou a konzistentnost’ou svojej judikatúry, rešpektujúcej judikatúru medzinárodných súdnych orgánov, efektívnou organizáciou svojej činnosti a samozrejme aj vysokou pracovnou aktivitou sudcov.

Za vonkajšie faktory podmieňujúce efektívnost' výkonu súdnej kontroly ústavnosti možno podla môjho názoru považovat' tie, ktoré pôsobia v zásade nezávisle od ústavného súdu, pričom ich pôsobenie môže ústavný súd ovplyvnit' len nepriamo, ked’že ho primárne ovplyvňujú iné zložky verejnej moci, resp. iné subjekty pôsobiace v rámci ústavnopolitického systému. Vonkajšie faktory podmieňujúce efektívnost' súdnej kontroly ústavnosti možno d'alej členit' na právne faktory a mimoprávne faktory, pod ktoré zahŕňam

17 Povojnové obdobie, v ktorom sa síce obnovila platnost' ústavnej listiny Československej republiky z roku 1920, ale ústavný súd sa už nekonštituoval.

18 Obdobie, v ktorom síce bolo ústavné súdnictvo na ústavnej úrovni vo vel’mi progresívnej podobe fixované (v 6. hlave ústavného zákona č. 143/1968 Zb. o československej federácii), ale nikdy nebol vydaný zákon na vykonanie ústavnej úpravy a federálny ani republikové ústavné súdy neboli ustanovené (k tomu viac pozri napr. DRGONEC, J: Ochrana ústavnosti Ústavným súdom Slovenskej republiky. Bratislava: EUROKÓDEX, 2010, s. 27 -31.

19 ŠEVČ́́K, V.: Ústavni soudníctví v praxi. Bulletin advokacie 1999, č. 11, s. 16. 
predovšetkým dosiahnutú úroveň politickej a právnej kultúry spoločnosti a zvlášt' jej politických elít, ako aj materiálne (rozpočtové, resp. finančné) zabezpečenie činnosti ústavného súdu.

Vnútornými faktormi a vonkajšími mimoprávnymi faktormi ovplyvňujúcimi efektívnost' výkonu ústavného súdnictva sa v mojej inauguračnej prednáške nechcem zaoberat'. Artikulácia a predovšetkým hodnotenie pôsobenia tzv. vnútorných faktorov mi vzhl'adom na moje súčasné pôsobenie v pozícii sudcu ústavného súdu a priori neprislúcha. Podrobná analýza, ako aj objektivizované hodnotenie pôsobenia tzv. mimoprávnych faktorov sú síce podl'a môjho názoru mimoriadne žiaduce, ale akcent na pôsobenie mimoprávnych faktorov by pravdepodobne nasmeroval závery tejto štúdie mimo rámca ústavného práva, čo by som považoval za nežiaduce, aj ked’ si uvedomujem ich zásadný vplyv na efektívny výkon súdnej kontroly ústavnosti, ktorý je nevyhnutné zohl'adňovat' aj pri formulovaní primárne ústavno-právnych záverov.

Z uvedeného vyplýva, že sa chcem venovat' podrobnejšej analýze pôsobenia tzv. (kl'účových) vonkajších právnych faktorov, ktoré môžu výraznejším spôsobom ovplyvnit' funkčnost' súdneho orgánu kontroly ústavnosti. K vonkajším právnym faktorom efektívneho fungovania súdnej kontroly ústavnosti faktorom treba podl'a môjho názoru zaradit' predovšetkým

a) primeraný rozsah a charakter právomocí ústavného súdu,

b) kvalitu a obsah právnej úpravy organizácie a činnosti ústavného súdu,

c) racionálnu právnu reguláciu kreovania personálneho zloženia ústavného súdu.

Práve na základe analýzy uvedených vonkajších právnych faktorov sa v d’alšej časti tejto štúdie pokúsim načrtnút' niektoré kl'účové problémy fungovania ústavného súdnictva $\mathrm{v}$ Slovenskej republike a formulovat' námety $\mathrm{k}$ ich riešeniu. Využívajúc pritom poznatky získané z praktického výkonu funkcie sudcu ústavného súdu sa pokúsim primárne o „vnútorný“ pohl'ad na tieto problémy, ktorý nie zriedka pri hl'adaní riešení absentuje.

\section{PRÁVNE FAKTORY PODMIEŇUJÚCE EFEKTÍVNOSŤ SÚDNEJ KONTROLY ÚSTAVNOSTI V SLOVENSKEJ REPUBLIKE}

\section{Rozsah a charakter právomocí Ústavného súdu Slovenskej republiky}

Ak má ústavný súd efektívne zabezpečovat' svoju klúčovú ústavnú funkciu nezávislého súdneho orgánu ochrany ústavnosti, ktorá zahŕňa (okrem iných) aj funkciu zabezpečovania ústavnosti výkonu verejnej moci a funkciu ústavného garanta ochrany l'udských práv a základných slobôd, musí byt' vybavený zodpovedajúcimi právomocami, ktorých obsah a rozsah by však nemal prekročit' racionálnu mieru, ktorá ešte reálne umožňuje, aby ústavný súd vykonával svoju rozhodovaciu činnost' $v$ požadovanej kvalite a v primeranom čase. Ústavný súd by navyše nemal byt' zat’ažený takými právomocami, ktoré mu vzhl'adom na jeho ústavné postavenie „systémovo“ nepatria, ked’že ich môžu v primeranej kvalite vykonávat' aj iné orgány súdneho typu.

Otázka racionálneho obsahu a rozsahu právomocí orgánu súdnej kontroly ochrany ústavnosti je zvlášt' aktuálna $v$ špecializovanom a koncentrovanom modely súdnej kontroly ústavnosti (z ktorého vychádza aj Ústava Slovenskej republiky), pre ktorý je príznačná mnohost' kompetencií organicky spojená s širším chápaním ústavného súdnictva. Ani pri širokom chápaní súdnej kontroly ústavnosti však nie je podl'a môjho názoru správne považovat' z ústavnoteoretického hl'adiska za sféru ústavného súdnictva všetko, čo ústavodarca, príp. zákonodarca zverí do právomoci ústavného súdu. Racionálny ústavodarca by mal v špecializovanom a koncentrovanom modely súdnej kontroly ústavnosti ústavnému súdu zverit' len také právomoci, ktoré sú bezprostredne spojené s plnením jeho kl’účovej ústavnej funkcie, t.j. súdnej 
ochrany ústavnosti. K takýmto právomociam patria systémovo také, pri ktorých realizácii ústavný súd môže, a spravidla aj musí, záväzne interpretovat' ústavu. ${ }^{20}$

Ak premietneme tieto teoretické východiská do slovenských reálií, tak môžeme konštatovat', že Ústava Slovenskej republiky už v pôvodnom znení zverila ústavnému súdu mimoriadne široký rozsah právomocí, ktoré mu v zásade umožňovali výkon jeho klúčovej ústavnej funkcie, ale na druhej strane sa medzi nimi nachádzali aj viaceré také právomoci, ktoré ústavodarca mohol (a aj mal) zverit' iným súdnym orgánom. Napriek uvedenému v d'alšom období dochádzalo a dochádza $\mathrm{k}$ systematickému rozširovaniu ústavných právomocí ústavného súdu. Zo sedemnástich doposial' vykonaných novelizácií ústavy došlo k rozšíreniu ústavných právomocí ústavného súdu prostredníctvom siedmich $\mathbf{z}$ nich (novelizácie ústavy vykonané ústavným zákonom č. 9/1999 Z.z., ústavným zákonom č. 90/2001 Z.z., ústavným zákonom č. 323/2004 Z. z., ústavným zákonom č. 463/2005 Z.z., ústavným zákonom č. 92/2006 Z.z., ústavným zákonom č. 161/2014 Z. z. a ústavným zákonom č. 71/2017 Z.z.), pričom navyše k rozšíreniu právomocí ústavného súdu došlo aj prostredníctvom ústavného zákona č. 357/2004 Z. z. o ochrane verejného záujmu pri výkone funkcií verejných funkcionárov a následne aj prostredníctvom jeho novelizácie vykonanej ústavným zákonom č. 545/2005 Z.z. (d’alej len „ústavný zákon o ochrane verejného záujmu“).

V nadväznosti na uvedené skutočnosti sa žiada podčiarknut', že podl'a mojich poznatkov žiadnu z uvedených ústavných zmien, až na výnimku súvisiacu s prípravou novelizácie ústavy vykonanej ústavným zákonom č. 90/2001 Z. z., jej navrhovatelia neprekonzultovali s ústavným súdom a nebola spojená s inými legislatívnymi opatreniami, ktoré by mohli prispiet' $k$ efektívnemu výkonu nových ústavných právomocí. ${ }^{21}$ Požiadavka konzultovat' obsah ústavných zmien dotýkajúcich sa právomocí ústavného súdu s ústavným súdom sa v uplynulom období javila o to naliehavejšia, že predovšetkým vzhl'adom na postupné rozširovanie pôvodných právomocí ústavného súdu došlo najmä v priebehu aktuálneho funkčného obdobia ústavného súdu (2007 - 2019) k dramatickému nárastu počtu návrhov na začatie konania pred ústavným súdom, ktorý nie zanedbatel’ným spôsobom ohrozil funkčnost' ústavného súdu ${ }^{22}$ a mal celkom nepochybne negatívny vplyv aj na kvalitu jeho rozhodovacej činnosti. ${ }^{23}$ Zároveň treba kriticky poznamenat', že domáca odborná literatúra na

20 K tomu pozri tiež BLAHOŽ, J.: op. cit. d., s. 363 a nasl.

21 Bezprostredne pred predložením návrhu spomenutej novelizácie ústavy do legislatívneho procesu sa uskutočnilo pracovné stretnutie navrhovatel’ov (skupiny poslancov národnej rady) s plénom ústavného súdu, ktorého výsledky boli premietnuté do finálnej verzie návrhu. Prostredníctvom novelizácie ústavy vykonanej ústavným zákonom č. 90/2001 Z. z. došlo $\mathrm{k}$ ustanoveniu štyroch nových právomoci ústavného súdu a $\mathrm{k}$ podstatnému rozšíreniu troch už skôr priznaných ústavných právomocí (vrátane právomoci rozhodovat' o ústavných st’ažnostiach), zároveň však bol počet sudcov ústavného súdu zvýšený z 10 na 13 sudcov.

$22 \mathrm{Z}$ dokumentov prístupných na internetových stránkach ústavného súdu (https://www.ustavnysud.sk/ochrana-ustavnosti). možno vyvodit' nasledovné štatistické údaje o varovnom náraste rozhodovacej agendy ústavného súdu: a) počas I. funkčného obdobia (v rokoch 1993 - 2000) bolo ústavnému súdu doručených 4 998, t. j. priemerne ročne 724 podaní, b) počas II. funkčného obdobia (v rokoch 2000 - 2007) počet podaní doručených ústavnému súdu stúpol na 12 466, čo predstavuje cca 1780 podaní ročne, c) v III. funkčnom období bolo v rokoch 2007- 2016 ústavnému súdu zatial' doručených 150542 podaní, čo predstavuje ročný priemer cca 15054 podaní (!).

23 Vo svojom konferenčnom príspevku na III. ústavných dňoch (OROSZ, L.: Ústavný súd Slovenskej republiky ako manufaktúra na ústavné st’ažnosti. In.: Ochrana l’udských práv a základných slobôd ústavnými súdmi a medzinárodnými súdnymi orgánmi - III. ústavné dni. Zborník príspevkov z medzinárodnej vedeckej konferencie. Košice: 23. september 2014. Košice: UPJŠ, 2014, s. 226 - 227) som negatívne dôsledky nárastu počtu ústavných st’ažnosti premietol do nasledovných téz:

„,,... a) výsledné produkty (rozhodnutia) ústavného súdu sú čoraz viac výsledkom práce poradcov ústavného súdu, než jeho sudcov (sudca $v$ horšom prípade len vezme materiály pripravené jeho poradcami na rokovanie pléna, či senátu ústavného súdu, v lepšom prípade si ich naštuduje a príp. aj upraví a doplní o vlastnú argumentáciu, a len vo výnimočných prípadoch rozhodnutie skoncipuje a pripraví osobne, pričom pri nadmernom nápade nových vecí sa žial pre duševné zdravie sudcu javi ako najlepši prvý prípad),

b) sudcovia sa sústred'ujú na vlastné rozhodnutia, t. j. rozhodnutia, ktoré im boli pridelené ako sudcom spravodajcom, na minimum sa znižuje „kolektívna tvorba rozhodnutia“, teda. aktívna ingerencia sudcu do rozhodnutia pripraveného jeho kolegom ..., 
tento kritický stav významnejším spôsobom neupozorňuje, naopak nie zriedka sa v nej objavujú námety na d’alšie rozširovanie právomocí ústavného súdu. Svetlú výnimku z tohto stavu predstavuje len niekol'ko (aj rozsiahlejších) analytických štúdií, ktorých autormi boli v zásade vždy samotní sudcovia ústavného súdu (vrátane emeritných). ${ }^{24}$

Napriek tomu, že tieto príspevky obsahujú aj celý rad námetov smerujúcich k redukčnému zásahu do ústavných právomocí ústavného súdu, nestretli sa v podstate so žiadnou relevantnou odozvou vo sfére výkonnej ani zákonodarnej moci. ${ }^{25}$ Priestorový rámec tejto štúdie neumožňuje dôkladnejšiu analýzu jednotlivých právomocí ústavného súdu, ktoré mu systémovo nepatria, resp. by mohli byt' bez zásadnejších koncepčných výhrad zverené do pôsobnosti iných orgánov súdneho typu, a preto sa s odkazom na moje predchádzajúce publikačné výstupy obmedzím na ich vymenovanie. Podl'a môjho názoru by mohli byt' ústavnému súdu odňaté najmä nasledovné právomoci:

a) právomoc rozhodovat' o volebných st’ažnostiach, t.j. o ústavnosti a zákonnosti volieb prezidenta, volieb do národnej rady, volieb do orgánov územnej samosprávy a volieb do Európskeho parlamentu podl'a čl. 129 ods. 2 ústavy, príp. aspoň právomoc rozhodovat' o ústavnosti a zákonnosti volieb do orgánov územnej samosprávy, ${ }^{26}$

b) právomoc rozhodovat' o st’ažnostiach proti výsledku referenda a o st'ažnostiach proti výsledku l'udového hlasovania o odvolaní prezidenta podl'a čl. 129 ods. 3 ústavy,

c) právomoc rozhodovat' kompetenčné spory medzi ústrednými orgánmi štátnej správy a právomoc rozhodovat' o tom, či je daná kontrolná pôsobnost' Najvyššieho kontrolného úradu Slovenskej republiky podl'a čl. 126 ods. 1 a 2 ústavy,

d) niektoré právomoci (ak už nie všetky) vyplývajúce $z$ ústavného zákona o ochrane verejného záujmu ${ }^{27}$, t.j. právomoc preskúmavat' rozhodnutia výboru národnej rady pre nezlučitel'nost' funkcií a d'alších orgánov ustanovených v čl. 9 ods. 1 písm. b) až d) tohto ústavného zákona, ktorými bola uložená verejnému funkcionárovi pokuta ustanovená v čl. 10 ods. 2 a 3 ústavného zákona o ochrane verejného záujmu, a najmä právomoc preskúmavat' roz-

c) rozhodnutia o ústavných st’ažnostiach sa čoraz viac začínajú z hl'adiska svojej štruktúry ale aj podstatnej časti svojho obsahu (najmä tej, ktorá tvorí všeobecnú argumentáciu), až priliš podobat' hoci ide o typovo neporovnatelné stažnosti, ked’že sa v pracovnom strese nie zriedka voli čo najjednoduchši prístup $k$ spracovaniu rozhodnutia ...,

d) v dôsledku rutinných a šablónovitých prístupov sa nemôže rozvíjat' ani kultivovat' judikatúra ústavného súdu, znižuje sa počet fundovaných odlišných stanovísk (sudcovia v dôsledku návalu práce spravidla rezignujú na ich spracovanie), zostáva minimum času na vzdelávanie, štúdium judikatúry iných súdov, štúdium odbornej literatúry, teda osobnostný rast sudcov,

e) prehlbuje sa nejednotnost' judikatúry jednotlivých senátov ...,

f) geometrickým nárastom nápadu ústavných st’ažností trpia rozhodnutia vo všetkých typoch konaní pred ústavným súdom, a zvlášt' tie, ktoré patria do pôsobnosti pléna ústavného súdu, ktoré by si objektívne vyžiadali vyšši stupeň súčinnosti a spolupráce sudcov a to aj preto, že spravidla majú dopad na d'aleko širší okruh adresátov, ako je to v prípade ústavných st'ažností.“.

24 Pozri najmä GAJDOŠíKOVÁ, L. - LUBY, J. - MOCHNÁČOVÁ, M. - OROSZ, L. - MACKO, R.: Rozširovanie právomoci Ústavného súdu a aktuálne problémy rozhodovacej praxe. In. 15 rokov Ústavy Slovenskej republiky. Zborník príspevkov z medzinárodnej vedeckej konferencie. Košice 6.- 7. septembra 2007. Košice: UPJŠ, 2008, s. 223 - 279; MACEJKOVÁ, I.: Právomoci Ústavného súdu Slovenskej republiky po dvadsiatich rokoch. Zborník príspevkov z medzinárodnej konferencie „Postavenie ústavných súdov a ich vplyv na právny poriadok štátu“. Košice 9. apríl 2012. Košice: EQUILIBRIA, s.r.o., 2013, s. 19 - 38; BÁRÁNY, E.: Dôsledky pret'aženosti ústavného súdu. In.: Ochrana l'udských práv a základných slobôd ústavnými súdmi a medzinárodnými súdnymi orgánmi - III. ústavné dni. Zborník príspevkov z medzinárodnej vedeckej konferencie. Košice: 23. september 2014. Košice: UPJŠ, 2014, s. 212 - 217.

25 Nepomohlo ani to, že ústavný súd iniciatívne pripravil ešte koncom minulého desatročia návrh novelizácie ústavy, podl’a ktorého sa výkon právomoci ústavného súdu rozhodovat' o ústavnosti a zákonnosti volieb, st'ažnostiach proti výsledku referenda a st’ažnostiach proti výsledku l'udového hlasovania o odvolaní prezidenta (čl. 129 ods. 2 a 3 ústavy) mal zverit' všeobecným súdom, a to napriek tomu, že tento návrh bol prekonzultovaný so zástupcami poslaneckých klubov národnej rade a nestretol sa z vecného hl'adiska so zásadnejšími výhradami.

$26 \mathrm{~K}$ tomu podrobnejšie OROSZ, L.: Rekodifikácia volebného zákonodarstva (I.). Justičná revue, roč. 63, č. 10 (2011), s. 1219 a nasl.

27 Závažnejšie výhrady by mohlo zrejme vyvolat' odňatie právomoci preskúmavat' rozhodnutia výboru národnej rady pre nezlučitel'nost' funkcií a d’alších orgánov ustanovených v čl. 9 ods. 1 písm. b) až d) ústavného zákona o ochrane verejného záujmu o strate mandátu alebo verejnej funkcie, ktorá je ustanovená v čl. 10 ods. 2 tohto ústavného zákona. 
hodnutia výboru národnej rady pre nezlučitel'nost' funkcií a d'alších orgánov ustanovených v čl. 9 ods. 1 písm. b) až d) tohto ústavného zákona, ktorými bola uložená pokuta príslušnému orgánu verejnej moci, resp. orgánu právnických osôb pre neposkytnutie ústavným zákonom predpokladanej súčinnosti (nesplnenie oznamovacej povinnosti), ${ }^{28}$ ktorá je ustanovená v čl. 10 ods. 4 ústavného zákona o ochrane verejného záujmu.

Aj ked' si viem predstavit', že by uvedené právomoci ústavného súdu boli zverené do pôsobnosti Najvyššieho súdu Slovenskej republiky, resp. iných všeobecných súdov, bolo by d’aleko vhodnejšie, ak by bola štruktúra orgánov súdnej moci rozšírená o Najvyšší správny súd, resp. sústavu správnych súdov, do ktorých pôsobnosti by výkon väčšiny vyššie spomenutých právomoci ústavného súdu systémovo patril. Bez ambície otvárat' tému potreby zriadenia „samostatného“ správneho súdnictva v Slovenskej republike, ktorá bezprostredne súvisí s potenciálnou redukciou právomocí ústavného súdu, sa obmedzím na poznámku, že diskusia na túto tému sa v našej odbornej verejnosti uzavrela skôr, ako sa vôbec začala. ${ }^{29}$

\section{Právna úprava organizácie a činnosti Ústavného súdu Slovenskej republiky}

Na efektívne fungovanie ústavného súdu nepochybne významným spôsobom vplývajú legislatívne základy jeho organizácie a činnosti. Právna úprava organizácie a činnosti ústavného súdu zahŕňa najmä právnu reguláciu jeho riadenia a zastupovania (navonok), rozdelenie výkonu jeho jednotlivých právomocí medzi ústavou, príp. zákonom ustanovené rozhodovacie útvary, procesné pravidla konania a rozhodovania týchto rozhodovacích útvarov, ako aj reguláciu organizačného, finančného a personálneho zázemia ústavného súdu. Kvalitná právna regulácia organizácie a činnosti ústavného súdu môže nepochybne výrazne napomôct' ku kvalitnému pIneniu jeho ústavných funkcií.

Právna regulácia organizácie a činnosti ústavného súdu je obsiahnutá jednak v ústave a tiež v ústavnom zákone o ochrane verejného záujmu, ale predovšetkým v zákone o ústavnom súde. Ústavná úprava (vrátane úpravy ústavným zákonom o ochrane verejného záujmu) zahŕňa:

a) spôsob kreovania predsedu a podpredsedu ústavného súdu, t.j. vedenia ústavného súdu [čl. 102 ods. 2 písm. s) a čl. 135 ústavy],

b) vymedzenie rozhodovacích útvarov ústavného súdu (plénum a senáty), rozdelenie pôsobnosti medzi nimi a podmienky ich uznášania sa (čl. 131 ústavy),

c) okruh subjektov oprávnených podávat' kvalifikované návrhy na začatie konania pred ústavným súdom (najmä čl. 130 ústavy, ale aj čl. 125a ods. 2, čl. 125b ods. 2, čl. 127 ods. 1 a čl. 127a ods. 1 ústavy, ako aj čl. 10 ods. 2, 3 a 4 ústavného zákona o ochrane verejného záujmu),

d) právne účinky rozhodnutí ústavného súdu vydávané v rámci jednotlivých typov konania (najmä čl. 125 ods. 5 a 6, čl. 125a ods. 3, čl. 125b ods. 3, čl. 127 ods. 2, čl. 127a ods. 2, čl. 128, čl. 129 ods. 8 a čl. 133 ústavy) a v niektorých prípadoch aj lehoty, v ktorých má ústavný súd o jednotlivých návrhoch na začatie konania rozhodnút' (čl. 125a ods. 3 a čl. 125b ods. 3 ústavy, čl. 10 ods. 2, 3 a 4 ústavného zákona o ochrane verejného záujmu).

Ústavná čast’ právnej regulácie organizácie a činnosti ústavného súdu v platnom a účinnom znení je podl’a môjho názoru v zásade vyhovujúca, a nemožno ju preto považovat' za faktor, ktorý by významnejšie ohrozoval funkčnost' ústavného súdu. Tento záver však vonkoncom neznamená, že nemožno de constitutione ferenda uvažovat' o jej skva-

28 V zmysle čl. 9 ods. 14 (v spojení s čl. 9 ods. 10 písm. a) ústavného zákona o ochrane verejného záujmu ide o pokutu vo výške zodpovedajúcej výške mesačného platu dotknutého verejného funkcionára (!).

29 K tomu viac pozri BARICOVÁ, J. - FECÍK, M. - FILOVÁ, A.: Kam smeruje správne súdnictvo v Slovenskej republike alebo je za horizontom Najvyšši správny súd? In. Ústavné dni, 25. výročie Ústavy Slovenskej republiky - VI. Ústavné dni. Košice: UPJŠ, 2018, s. 123 - 144. 
litnení. Bez ambície ponúknut' komplexný a podrobnejšie odôvodnený okruh námetov na skvalitnenie tejto časti ústavnej regulácie sa domnievam, že by bolo prospešné uvažovat'

a) o zmene ústavnej regulácie ustanovovania predsedu a podpredsedu ústavného súdu (podl'a môjho názoru by k zvýšeniu autority ale aj legitimity funkcionárov ústavného súdu prospelo, ak by predsedu a podpredsedu ústavného súdu volilo plénum ústavného súdu zo svojich radov, príp. ich vymenúval nad'alej prezident, ale na návrh pléna ústavného súdu, ktorým by bol viazaný), ${ }^{30}$

b) o ustanovení oprávnenia samosudcu (sudcu spravodajcu) rozhodovat' samostatne o niektorých procesných otázkach (k tomu viac nižšie),

c) o ustanovení oprávnenia senátu ústavného súdu prerušit' konanie o ústavnej st’ažnosti, ak v konaní dospeje k záveru, že k porušeniu ústavou, resp. medzinárodnou zmluvou garantovaného práva alebo slobody došlo aplikáciou právneho predpisu, ktorý je $\mathrm{v}$ rozpore $\mathrm{s}$ ústavou a predložit' vec plénu ústavného súdu, aby rozhodlo o tejto otázke v rámci konania o súlade právnych predpisov, ${ }^{31}$

d) v záujme stabilizácie (a ústavnej ochrany) zakotvit’ priamo v ústave právo sudcu pripojit' $\mathrm{k}$ rozhodnutiu väčšiny pléna, resp. senátu ústavného súdu odlišné stanovisko, ktoré možno považovat' za mimoriadne efektívny prostriedok kultivácie a perspektívneho rozvoja judikatúry ústavného súdu a minimálne nepriamo aj prostriedok slúžiaci k zvyšovaniu jej kvality.

Rozhodujúca čast' právnej regulácie organizácie činnosti ústavného súdu, predovšetkým procesné pravidla a podmienky konania a rozhodovania pléna a senátov ústavného súdu, je obsiahnutá $\mathbf{v}$ zákonnej úprave - v zákone o ústavnom súde ( $\$ 18$ a nasl.). Aj ked’ predmetná právna úprava má podl’a môjho názoru solídne kvalitatívne parametre, o problémom súvisiacich s jej interpretáciou a aplikáciou by bolo možné a zrejme aj prospešné venovat' viacdňové vedecké konferencie. ${ }^{32}$ Ked’že priestorový rámec tejto štúdie je limitovaný, obmedzím sa len na artikulovanie dvoch (navzájom prepojených) námetov, ktoré by výraznejším spôsobom mohli vplývat' na efektivitu činnosti ústavného súdu, zvlášt' k vytvoreniu podmienok na poskytovanie ústavnej ochrany $\mathrm{v}$ primeranom čase.

Podl’a platnej zákonnej úpravy je konanie pred ústavným súdom koncipované ako „dvojfázové“, ked’že pozostáva z predbežného prerokovania každého návrhu na začatie konania na neverejnom zasadnutí pléna, resp. senátu ústavného súdu bez prítomnosti navrhovatel'a (toto štádium konania je upravené predovšetkým v $§ 25$ zákona o ústavnom súde) a konania vo veci samej. Dvojfázovost' konania sa v zásade vzt’ahuje na každý typ konania pred ústavným

30 Akceptáciou tohto námetu by sa odstránil aj potenciálny interpretačný spor o výklad ústavy, spočívajúci v hl’adaní odpovede na otázku, či je prezident oprávnený nielen vymenovat', ale aj odvolat' predsedu alebo podpredsedu ústavného súdu pred uplynutím ich funkčného obdobia sudcu, Pre vznik tohto interpretačného sporu vytvára živnú pôdu „napätie“ medzi dikciou čl. 102 ods. 2 písm. s) ústavy a znením čl. 135 ústavy. Na túto otázku boli v domácej odbornej literatúre už kvalifikovaným spôsobom vyslovené rozdielne názory. Na jednej strane ide o názor T. Lalíka, ktorý v štúdii LAALÍK, T.: Právomoc prezidenta odvolávat' predsedu a podpredsedu ústavného súdu. Justičná revue, roč. 66, č. 8-9 (2014), s. 1067 1087, argumentuje, že výkonu právomoci prezidenta odvolávat' funkcionárov ústavného súdu je podla súčasnej právnej úpravy „,nemožný“, resp. minimálne aspoň „,nevhodný“. Na túto štúdiu takmer bezprostredne reagoval nesúhlasne B. Ba$\log$ v štúdii BALOG, B.: Ad: „Právomoc prezidenta odvolávat’ predsedu a podpredsedu ústavného súdu. Justičná revue, roč. 67, č.2 (2015), s. 219 - 224. Argumentáciu B. Baloga v prospech existencie právomoci prezidenta odvolávat’ funkcionárov ústavného súdu následne podrobnejšie rozvíja vo svojich publikačných výstupoch J. Drgonec (pozri najmä DRGONEC, J.: Ústava Slovenskej republiky. Teória a prax. Bratislava: C.H. Beck, 2015, s. 1472 - 1476).

31 Išlo by o obdobné oprávnenie akým disponuje senát Ústavného súdu Českej republiky podl’a $§ 78$ zákona č. 182/1993 Sb. o Ústavním soudu v znení neskorších predpisov (viac $\mathrm{k}$ interpretácii a aplikácii označeného zákonného ustanovenia pozri napr. FILIP, J. - HOLLÄNDER, P. - ŠIMÍČEK, V.: Zákon o Ústavním soudu. Komentář. 2. prepracované a rozšírené vydaní. Praha: C.H. Beck, 2007, s. 615 a nasl.). Domnievam sa však, že zakotvenie tohto oprávnenia, ktorého aplikácia by nepochybne prospela možnostiam ústavného súdu poskytovat efektívnejšie ochranu ústavou garantovaných práv a slobôd, len na úrovni zákona, by mohla byt' problematická.

32 Plénum ústavného súdu v zložení sformovanom po roku 2007 podrobilo zákon o ústavnom súde hlbokej analýze, ktorá vyústila už v koncom roka 2008 do uceleného legislatívneho návrhu, ktorý sa postupne dopíňal, pričom orgány pôsobiace vo sfére výkonnej a zákonodarnej moci ho mali, resp. majú bez patričnej odozvy k dispozícii už niekol'ko rokov (!). 
súdom, ked’že platná zákonná úprava nedáva dostatočný priestor pre jej prípadnú inú interpretáciu, ${ }^{33}$ čo podl’a môjho názoru v niektorých prípadoch zbytočne zat’ažuje sudcov a má negatívny vplyv na poskytovanie ústavnej ochrany v primeranom čase, ked’že v podstate každý návrh na začatie konania musia rozhodovacie útvary ústavného súdu prerokovat' (najmenej) dvakrát. Aj preto by bolo žiaduce zmenit' zákonnú úpravu tak, aby nebola dvojfázovost' konania pred ústavným súdom obligatórna, resp. sa nevzt’ahovala na všetky typy konaní.

Druhý námet sa týka rozhodovania o odmietnutí návrhu na začatie konania pri jeho predbežnom prerokovaní. Dôvody, pre ktoré môže (resp. musí) senát alebo plénum ústavného súdu návrh na začatie konania odmietnut' sú taxatívnym spôsobom vymedzené v $§ 25$ ods. 2 zákona o ústavnom súde. $\mathrm{V}$ prevažnej miere ide o dôvody formálneho charakteru, ktorých posúdenie je z odborného hl'adiska v zásade jednoduché. Preto by sa posudzovanie existencie formálnych dôvodov na odmietnutie st’ažnosti mohlo podl'a môjho názoru bez zásadnejších obáv zverit' do samostatnej pôsobnosti sudcu spravodajcu (samosudcu), ktorý podl'a platnej zákonnej úpravy môže samostatne rozhodovat' len o odložení podania, ak z jeho obsahu zistí, že nejde o návrh na začatie konania ( $\$ 23$ a zákona o ústavnom súde). ${ }^{34}$

K takýmto formálnym dôvodom, na základe ktorých by samosudca mohol sám odmietnut' návrh na začatie konania by mali podl'a môjho názoru patrit' najmä odmietnutie návrhu z dôvodov nedostatku právomoci ústavného súdu, nesplnenia zákonom predpísaných náležitostí, neprípustné návrhy, ako aj návrhy podané niekým zjavne neoprávneným a tiež návrhy podané oneskorene, t.j. v pôsobnosti senátu, resp. pléna ústavného súdu by zostala len možnost' odmietnut' pri predbežnom prerokovaní návrh, ktorý je zjavne neopodstatnený, príp. tento dôvod odmietnutia návrhu na začatie konania pred ústavným súdom zo zákonnej úpravy (vzhl'adom na jeho problematickost') vypustit' (!). ${ }^{35}$ Aj na základe mojich praktickým skúseností sa domnievam sa, že ide $\mathrm{v}$ zásade o procesne jednoduché rozhodovanie, ktoré by na jednej strane v počiatočnom štádiu konania pred ústavným súdom výrazne odbremenilo (ostatných) sudcov a nemalo by ohrozit’ štandardy poskytovanej ústavnej ochrany, ktoré by sa navyše príp. dali eliminovat' oprávnením navrhovatel'a podat' proti odmietajúcemu rozhodnutiu samosudcu námietky, o ktorých by rozhodoval senát, resp. plénum ústavného súdu.

\section{Právna regulácia kreovania personálneho zloženia ústavného súdu}

Nie je potrebné osobitne zdôrazňovat', že základným predpokladom spoločenskej autority a dôveryhodnosti súdneho orgánu ochrany ústavnosti je jeho kvalitná, transparentná a konzistentná judikatúra, ktorá je primárne podmienená odbornými a osobnostnými kvalitami sudcov. Pri určitom zjednodušení možno tvrdit', že kl'účovým predpokladom efektívneho výkonu súdnej kontroly ústavnosti je kvalitný výber sudcov. Výber sudcov je právne regulovaný, pričom kvalita právnej regulácie kreovania personálneho zloženia ústavného súdu nepochybne má zásadný vplyv na výsledky tohto procesu, teda personálne zloženie súdu. V čase ked' som dopisoval rukopis tejto štúdie akcelerovala politická, odborná i spoločenská diskusia o možnostiach, resp. potrebe skvalitnenia ústavnej a zákonnej úpravy kreovania sudcov ústavného súdu, v ktorej sa objavilo viacero hodnotných, námetov. ${ }^{36}$

33 Plénum ústavného súdu sa v uznesení PLz. ÚS 1/07 z 2. mája 2007 priklonilo k dvojfázovosti konania aj vo veciach ochrany verejného záujmu podla ústavného zákona o ochrane verejného záujmu, pri ktorom sa črtali možnosti od dvojfázovosti konania upustit'.

34 Ked’že aj v tomto prípade ide nielen de facto, ale aj de iure o rozhodnutie o návrhu (podaní), možno diskutovat' o jeho zlučitel'nosti s ústavou, ktorá sudcu (samosudcu) ústavného súdu nezahŕňa k jeho rozhodovacím útvarom (!).

35 Vo svojej podstate možno odmietnutie návrhu na začatie konania ako zjavne neopodstatneného kvalifikovat’ ako „negatívne meritórne rozhodnutie“ ústavného súdu, ktoré senát resp. plénum ústavného súdu vydáva v podmienkach, v ktorých je navrhovatel' v zásade zbavený akejkol'vek procesnej ochrany.

36 Základný vecný rámec verejnej diskusie k otázkam skvalitnenia právnej regulácie ustanovovania sudcov ústavného súdu vytvorili dokumenty sprístupnené verejnosti v poslednej dekáde mája 2018; 
Dôvody, pre ktoré dochádza práve $\mathrm{v}$ tomto období $\mathrm{k}$ zintenzívneniu verejnej diskusie o optimalizácii právnej regulácie kreovania sudcov ústavného súdu práve v tomto čase sú objektívne podmienené viacerými skutočnost’ami;

a) v prvom rade tým, že 16. februára 2019 uplynie funkčné obdobie deviatim z trinástich sudcov ústavného súdu, z čoho vyplýva ,povinnost““ národnej rady zvolit' do začiatku budúceho kalendárneho roka 18 (vhodných) kandidátov na sudcov ústavného súdu,

b) skutočnost'ou, že v priebehu „tretieho“ funkčného obdobia pôsobil ústavný súd, v dôsledku dlhotrvajúceho sporu medzi ústavnými orgánmi (prezidentom a národnou radou, resp. jej koaličnou väčšinou, s nezanedbatel'nou ,asistenciou“ samotného ústavného súdu) viac ako tri roky v nekompletnom zložení, čo malo nepochybne negatívny vplyv na efektívny výkon kontroly ústavnosti a vyvoláva odôvodnené obavy z toho, či strany sporu bude spôsobilé zabezpečit', aby sa po 16. februári 2019 zachovala funkčnost' ústavného súdu,

c) skutočnost'ou, že Benátska komisia vo svojom dokumente „Stanovisko k menovaniu sudcov ústavného súdu“ odporúčala Slovenskej republike, aby zvážila vykonanie určitých zmien v právnej regulácii ustanovovania sudcov ústavného súdu, ${ }^{37}$

d) rastom nedôvery občanov $\mathrm{k}$ (domácim) inštitúciám, ${ }^{38}$ ktorá akcelerovala v prvej polovici roku 2018 (zvlášt' v období po vražde novinára Jána Kuciaka a jeho partnerky Martiny Kušnírovej),

e) skutočnost’ou, že v súčasnosti platný a účinný kreačný mechanizmus sudcov ústavného súdu objektívne obsahuje viacero úskalí ${ }^{39}$.

a) iniciatívny dokument „Návrh kreačného mechanizmu Ústavného súdu“, vypracovaný skupinou 38 verejne známych odborníkov zo sféry právnej praxe i právnej teórie, $\mathrm{O}$ tomto dokumente viac pozri napr.: Odborníci navrhujú zásadné zmeny pri vol'be ústavných sudcov. Sme, 22. máj 2018.

Dostupné na internete https://domov.sme.sk/c/20831701/odbornici-navrhuju-zasadne-zmeny-pri-volbe-ustavnychsudcov.html.), a

b) návrhy novelizácie ústavy a zákona o ústavnom súde vypracované ministerstvom spravodlivosti SR, ktoré boli 28. mája 2018 predložené do medzirezortného pripomienkového konania (Minister spravodlivosti SR Gábor Gál predstavil navrhované zmeny pri vol'be sudcov ústavného súdu)

Dostupné na internete: https://www.justice.gov.sk/Stranky/aktualitadetail.aspx?announcementID=2342.

$\mathrm{V}$ podstate $\mathrm{v}$ rovnakom čase bola do rúk odbornej verejnosti distribuovaná aj publikácia Výber ústavných sudcov. Prístupy $k$ spravodlivosti . bariéry a východiská 13. Banská Bystrica: VIA IURIS, 2018, s. 50, ktorá obsahuje taktiež množstvo zaujímavých podnetov obsiahnutých v príspevkoch, ktoré odzneli na konferencii VIA IURIS s rovnomenným názvom „Výber ústavných sudcov“ (Bratislava, 7. novembra 2017). Povšimnutiahodné námety bolo možné v tomto čase nájst' aj v dennej tlači, pozri napr. rozhovor: Bývalý sudca Bröstl: Vládne strany chcú sudcov, ktoré ich budú kryt'. Denník N, 5. apríla 2018 (https://dennikn.sk/1083799/brostl-vladne-strany-chcu-ustavnych-sudcov-ktori-ich-budu-kryt/?ref=list).

37 V bode 77 Stanoviska Benátskej komisie sa uvádza:

„Aby v budúcnosti takéto situácie nenastali, Benátska komisia odporúča zvážit' nasledujúce návrhy pri najbližšej reforme procesov týkajúcich sa ústavného súdu:

1. Zaviest' kvalifikovanú väčšinu pre vol'by kandidátov na sudcov ústavného súdu spolu s vhodnými protiblokovými mechanizmami (potrebná novela ústavy). ...

3. Prezident Slovenskej republiky a jeho zástupcovia by sa mali aktívne zúčastňovat' procesu posudzovania kandidátov $v$ parlamente, aby sa tak zabránilo d’alšiemu posudzovaniu kandidátov. ... “.

$38 \mathrm{~K}$ tomu pozri napr. Vláde ani parlamentu nedôveruje takmer polovica l’udí. Aktuality.sk, 4.5. 2018. Dostupné na internete: https://www.aktuality.sk/clanok/335530/prieskum-vlade-ani-parlamentu-nedoveruje-takmer-polovica-ludi/.

39 Pred viac ako dvoma rokmi som kl'účové úskalia slovenského modelu ustanovovania sudcov ústavného súdu vo svojom príspevku na medzinárodnej vedeckej konferencii [OROSZ, L.: O aktuálnych problémoch pri ustanovovaní sudcov ústavného súdu (pričiny a dôsledky). In.: CVRČEK, F. - JERMANOVÁ, H.: Metamorfózy práva ve střední Evropě V. Překrásny nový svět nebo ostrov ?.Plzeň: Aleš Čeněk, 2016, s. 77-78] vo všeobecnej rovine pomenoval nasledovne:

„1. K vol'be kandidátov na funkcie sudcov postačuje nadpolovičná väčšina prítomných poslancov parlamentu, čo $v$ podmienkach ostrého politického zápasu vylučuje akýkolvek reálny vplyv opozície na výber sudcov;

2. Sudcami ústavného súdu sa môžu potenciálne stat' aj lídri kl'účových politických strán, resp. osoby, ktoré v čase ustanovenia do funkcie vykonávajú exponované funkcie v ústavných orgánoch, či politických stranách;

3. Ústavná ani zákonná úprava neustanovuje pre národnú radu žiadne lehoty na uskutočnenie procesu výberu kandidátov na funkciu sudcov ústavného súdu, čo hypoteticky vytvára priestor pre znefunkčnenie ústavného súdu (odkladanim ,, vol'by" kandidátov na uvol’nené miesta sudcov, resp. „,nedovolením “ kandidáta chýbajúceho do dvojnásobného počtu kandidátov, ktori sa musia prezidentovi predložit').

4. Ústavná úprava je založená na požiadavke dosiahnutia konsenzu dvoch najvy̌ších ústavných orgánov (národnej rady a prezidenta, pričom oba tieto ústavné orgány sú legitimované v priamych volbách občanmi disponujúcimi aktívnym 
V priebehu verejnej diskusie sa objavil celý rad námetov, ktorých premietnutie do ústavnej alebo zákonnej úpravy by nepochybne mohlo prispiet' k skvalitneniu kreačného mechanizmu, zvýšeniu transparentnosti a tým aj dôveryhodnosti procesu kreovania sudcov a snád' aj aspoň k jeho čiastočnému odpolitizovaniu. Napriek tomu nepovažujem za nutné analyzovat' vecný rámec diskusie o prípadných zmenách právnej regulácie kreovania sudcov ústavného súdu, a to nielen $\mathrm{z}$ dôvodu obmedzených priestorových rámcov tejto štúdie, ale zvlášt' s ohl'adom na skutočnost', že výsledky tejto diskusie budú v konečnom dôsledku ,zhmotňovat"“ nie odborníci, ale poslanci zákonodarného zboru, ktorí nepochybne budú rozhodovat' primárne „politicky“ (aj ked' nepochybne pod tlakom občianskej spoločnosti), čo im dost' dobre nemožno zazlievat', ked'že predmetom nie zanedbatel'nej časti rozhodovacej činnosti ústavného súdu v každom štáte je aj ,politika.“ 40 Skutočnost', že záväzok vlády, ktorá vzišla z parlamentných volieb uskutočnených 5. marca 2016 navrhnút' „,.. prijatie ústavného zákona, ktorý sa bude týkat' kreácie ústavného súdu pri prehodnoteni funkčného obdobia sudcov, kvalifikačných kritérii na osobu sudcu s dôrazom na odbornú a morálnu zdatnost', vyjasnenie právomoci prezidenta v procese výberu....", zapísaný v jej programovom vyhlásení, sa (možno) dostáva do realizačnej fázy až v kritickom čase, nevzbudzuje u mňa vel'ký optimizmus.

Vzhl'adom na funkcie, ktoré ústavný súd plní v ústavnom mechanizme demokratického a právneho štátu však treba privítat' to, že problematika právnej regulácie kreovania ústavného súdu sa stala predmetom seriózneho verejného diskurzu, a to bez ohl'adu na skutočnost', či k zmenám platnej ústavnej a zákonnej úpravy skutočne dôjde. V tejto súvislosti považujem za potrebné zdôraznit', že skvalitnenie právnej regulácie výberu sudcov ústavného súdu síce môže prispiet' k výberu kvalitných kandidátov, ale na druhej strane ani seba lepšia právna regulácia ustanovovania sudcov ústavného súdu nie je zárukou toho, že sa sudcami aj skutočne stanú odborne, morálne i l’udsky najvhodnejší kandidáti a to nielen preto, že $\mathrm{v}$ hl'adaní „najlepších“ je vždy prítomná vysoká miera subjektivizmu, ale hlavne preto, že výber „najlepších“ je primárne závislý od aktuálnej úrovne politickej a právnej úrovne a v tejto súvislosti najmä ochoty politických elít poslat' na ústavný súd naozaj „najlepších“. Skutočnost', že o tejto problematike prebieha verejná diskusia však podl'a môjho názoru sama osebe vy-

volebným právom) pri personálnom kreovani ústavného súdu, čo potenciálne môže vyústit’ do nefunkčnosti tohto mechanizmu, a to najmä vtedy, ak je výber kandidátov v národnej rade neprimerane spolitizovaný, ako aj vtedy, ak sú vzt’ahy medzi parlamentnou väčšinou a prezidentom vyhrotené.

5. Ústavná ani zákonná úprava nedáva žiadne záruky k tomu, aby sa dosiahlo profesionálne a odborne vyvážené personálne zloženie ústavného súdu (primerane zastúpenie zástupcov pochádzajúcich z akademického prostredia, justičného prostredia, resp. prostredia iných právnických povolaní). “

Na citovanom hodnotení úskalí slovenského kreačného modelu nemám dôvod nič zásadného menit', aj ked’ po sérií rozhodnutí ústavného súdu - náleze sp. zn. III. ÚS 571/2014 zo 17. marca 2015 (k jeho kritike pozri napr. MAZÁK, J.: Výber sudcov Ústavného súdu Slovenskej republiky. Záruka účinnej ochrany ústavnosti. In.: Výber ústavných sudcov....op. .cit. publikácia, s. 21 -22), uznesení sp. zn. PL. ÚS 45/2015 z 28. októbra 2015 a náleze sp. zn. I. ÚS 575/2016 zo 6. decembra 2016, ktorý na jednej strane zásadným spôsobom prispel k obsadeniu dlhodobo uprázdnených sudcovských miest, ale na druhej strane bol bezprostredne po svojom vyhlásení vystavený sústredenej kritike odbornej verejnosti (pozri napr. KUBINA, P.: Prezident zistil aké to je, ked’ sa žiaden ústavný princíp nemôže citit' v bezpečí. Denník N, 7. 12. 2017, DRGONEC, J.: Postup ústavného súdu páchne svojvôlou. Denník N, 11. 12. 2017, DRGONEC, J.: Všetko, čo by ste mali vediet'o tom, ako ústavni sudcovia prikázali Kiskovi konat'. Denník N, 15. 12. 2017; BERDISOVÁ, L.: Horcruxy na Ústavnom súde. Sme, 16. 12. 2017), sa žiada bod 4 týkajúci sa požiadavky dosiahnutia konsenzu národnej rady a prezidenta modifikovat' do tej podoby, že ide o model, ktorý možno nazvat' ako «,,nucenou kolaboraci“ (prezidenta), nebot' dáva národní radè možnost de facto dotlačit prezidenta $k$ určitému rozhodnutí - t.j.navrhnout na uvolnené misto takové dva kandidáty, z nichž oba konvenujú k aktuální parlamentni většine.» (VYHNÁNEK, L: Jak vybirat soudce.? Hledáni modelu pro mladé demokracie. In. Výber ústavných sudcov....op. .cit. publikácia, s. 30). Vd’aka označeným rozhodnutiam ústavného súdu sa obmedzili možnosti ,zablokovania“ platného kreačného modelu ustanovovania sudcov ústavného súdu, ale na druhej strane sa z neho vytratili prvky del'by moci a vzájomných bŕzd a protiváh.

$40 \mathrm{~K}$ tomu pozri OROSZ, L.: Rast moci ústavných súdov - limity a úskalia. ...op. cit. d., s. 198 a nasl., alebo KELEMEN, K.: Appointment of Constitutional Judges in a Comparative Perspektive - with a Proposal for a New Model for Hungary. Acta Iuridica Hungarica, Vol. 54, No. 1, pp. 5 -23 (2013).

Dostupné tiež na internete: https://papers.ssrn.com/sol3/papers.cfm?abstract_id=2229184. 
tvára pozitívny tlak na zvýšenie zodpovednosti tých, ktorí budú v nasledujúcich mesiacoch kreovat' nový ústavný súd.

\section{ZÁVER}

Koncentrujúc doposial' formulované idey a námety, ktorých realizácia by mohla podl'a môjho presvedčenia napomôct' vytváraniu podmienok pre efektívnejší výkon súdnej kontroly ústavnosti v Slovenskej republike, možno konštatovat', že príslušné ústavné orgány pristupujú k napínaniu pozitívneho záväzku chránit' a zvel’ad'ovat' efektívne ústavné súdnictvo ako ústavou chránenú hodnotu, nie zriedka macošsky. Potvrdzujú to nepriamo aj výsledky objektívnej komparatívnej analýzy spracovanej k 20. výročiu konštituovania Ústavného súdu Slovenskej republiky, z ktorej sa uvádza, že ,z porovnávaných súdnych orgánov ochrany ústavnosti má Ústavný súd Slovenskej republiky najväčš nápad podaní, najviac rozhodnutí, ako aj najviac kompetencií. Napriek najširšiemu okruhu právomocí, ako i najvyššej vytaženosti sa však Ústavný súd Slovenskej republiky z hl'adiska materiálneho (vrátane finančného) a personálneho zabezpečenia v rámci porovnania s ústavnými súdmi okolitých stredoeurópskych krajín pohybuje na dolnej hranici (či už ide o počet zamestnancov, sudcov alebo poskytnutých rozpočtových prostriedkov). “ ${ }^{41}$

\section{KLÚČOVÉ SLOVÁ}

súdna kontrola ústavnosti, efektívne ústavné súdnictvo, Ústavný súd Slovenskej republiky, sudcovia ústavného súdu.

\section{KEY WORDS}

judicial review of constitutionality, effective constitutional judiciary, Constitutional Court of Slovak Republic, judges of constitutional court

\section{POUŽITÁ LITERATÚRA}

1. BALOG, B.: Ad: „Právomoc prezidenta odvolávat' predsedu a podpredsedu ústavného súdu. Justičná revue, roč. 67, č. 2 (2015), s. 219 - 224.

2. BÁRÁNY, E.: Dôsledky pret’aženosti ústavného súdu. In: Ochrana l’udských práv a základných slobôd ústavnými súdmi a medzinárodnými súdnymi orgánmi - III. ústavné dni. Zborník príspevkov z medzinárodnej vedeckej konferencie. Košice: 23. september 2014. Košice: UPJŠ, 2014, s. 212 - 217. ISBN 978-80-8152-207-9.

3. BERDISOVÁ, L.: Horcruxy na Ústavnom súde. Sme, 16. 12. 2017

4. BARICOVÁ, J. - FECÍK, M. - FILOVÁ, A.: Kam smeruje správne súdnictvo v Slovenskej republike alebo je za horizontom Najvyšší správny súd ?. In: Ústavné dni, 25. výročie Ústavy Slovenskej republiky - VI. Ústavné dni. Košice: UPJŠ, 2018, s. 123 144. ISBN 978-80-8152-600-8.

5. BLAHOŽ, J.: Soudní kontrola ústavnosti. Srovnávací prehled. Praha: ASPI Publisching, s.r.o., 2001, s. 492. ISBN 80-86395-09-X.

6. Bývalý sudca Bröstl: Vládne strany chcú sudcov, ktoré ich budú kryt'. Denník N, 5. apríla 2018. https://dennikn.sk/1083799/brostl-vladne-strany-chcu-ustavnych-sudcov-ktori-ichbudu-kryt/?ref=list).

7. CORWIN, E.: Lectures on the Constitution of the United States. Boston: b.m., 1939.

41 MACEJKOVÁ, I.: Právomoci Ústavného súdu ... op. cit. d., s. 35. 
8. DICEY, A.V.: Introduction to the Study of the Law of the Constitution. London: b.m., 1927. Dostupné na https://doi.org/10.1007/978-1-349-17968-8.

9. DRGONEC, J: Ochrana ústavnosti Ústavným súdom Slovenskej republiky. Bratislava: EUROKÓDEX, 2010, s. 416. ISBN 978-80-89447-25-1.

10. DRGONEC, J.: Ústava Slovenskej republiky. Teória a prax. Bratislava: C.H. Beck, 2015, s. 1622. ISBN 978-8089603-39-8.

11. DRGONEC, J.: Postup ústavného súdu páchne svojvôl'ou. Denník N, 11. 12. 2017. DRGONEC, J.: Všetko, čo by ste mali vediet' o tom, ako ústavní sudcovia prikázali Kiskovi konat'. Denník N, 15. 12. 2017.

12. FILIP, J. - HOLLÄNDER, P. - ŠIMÍČEK, V.: Zákon o Ústavním soudu. Komentář. 2. přepracované a rozšírené vydaní. Praha: C.H. Beck, 2007, s. 896. ISBN 978-80-7197599-5.

13. GAJDOŠÍKOVÁ, L'. - LUBY, J. - MOCHNÁČOVÁ, M. - OROSZ, L. - MACKO, R.: Rozširovanie právomocí Ústavného súdu a aktuálne problémy rozhodovacej praxe. In: 15 rokov Ústavy Slovenskej republiky. Zborník príspevkov z medzinárodnej vedeckej konferencie. Košice 6.- 7. septembra 2007. Košice: UPJŠ, 2008, s. 223 - 279. ISBN 978-807097-699-9.

14. GIBA, M.: Súdna kontrola ústavnosti vo Francúzsku. Bratislava: Wolters Kluwer, s.r.o., 2017, s. 278. ISBN 978-80-8168-741-9.

15. GRANAT, M.: Sadova kontrola konstytucyjności prawa w państwach Europy Środkowej i Wschodniej. Warszawa: Wydawnictwo Sejmowe, 2003, s. 325. ISBN 83-7059-619-3.

16. KELEMEN, K.: Appointment of Constitutional Judges in a Comparative Perspektive with a Proposal for a New Model for Hungary. Acta Iuridica Hungarica, roč. 54, č. 1 (2013), s. 5 -23. Dostupné na https://doi.org/10.1556/ajur.54.2013.1.2.

17. KLOKOČKA, V.: Ústavní zřízení evropských států. Praha: Linde, 1996. 415 s. ISBN 807-20-1010-7.

18. KUBINA, P.: Prezident zistil aké to je, ked' sa žiaden ústavný princíp nemôže cítit' v bezpečí. Denník N, 7. 12. 2017.

19. Lord LESTER of Herne Hill - OLIVER, Dawn. (ed).: Constitutional and Human Rights. London: b.m., 1997.

20. LALÍK, T.: Právomoc prezidenta odvolávat' predsedu a podpredsedu ústavného súdu. Justičná revue, roč. 66, č. 8-9 (2014), s. 1067 - 1087.

21. MACEJKOVÁ, I.: Právomoci Ústavného súdu Slovenskej republiky po dvadsiatich rokoch. In: Zborník príspevkov z medzinárodnej konferencie „Postavenie ústavných súdov a ich vplyv na právny poriadok štátu“. Košice 9. apríl 2012. Košice: EQUILIBRIA, s.r.o., 2013, s. 19 - 38. ISBN 978-80-969989-6-8.

22. MAZÁK,J. : Výber sudcov Ústavného súdu Slovenskej republiky, záruka účinnej ochrany ústavnosti. In: Výber ústavných sudcov. Prístupy k spravodlivosti. Bariéry a východiská 13. Banská Bystrica: VIA IURIS, 2018, s. 16 - 22. ISBN 978-80-89805-013.

23. Minister spravodlivosti SR G. Gál predstavil navrhované zmeny pri vol'be sudcov ústavného súdu https://www.justice.gov.sk/Stranky/aktualitadetail.aspx?announcementID=2342.

24. MLSNA, P.: Ústavní soudníctví ve státovědnem myslení. Právnik, 2009, č. 10, s. 1021 1029. 
25. Odborníci navrhujú zásadné zmeny pri vol'be ústavných sudcov. Sme, 22. máj 2018. https://domov.sme.sk/c/20831701/odbornici-navrhuju-zasadne-zmeny-pri-volbeustavnych-sudcov.html.

26. Ochrana ústavnosti a Ústavy Slovenskej republiky v rozhodovacej činnosti Ústavného súdu Slovenskej republiky za rok 2016. https://www.ustavnysud.sk/ochrana-ustavnosti.

27. Ochrana ústavnosti a Ústavy Slovenskej republiky v rozhodovacej činnosti Ústavného súdu Slovenskej republiky za rok 2017. https://www.ustavnysud.sk/ochrana-ustavnosti.

28. OROSZ, L.: O preventívnej kontrole ústavnosti. Právny obzor, 89, 2006, č. 6, s 485 502.

29. OROSZ, L.: Ústavy štátov strednej a východnej Európy (pokus o všeobecnú charakteristiku).Právnik, roč. 148, č. 11, 2009, s. 1148 - 1157.

30. OROSZ, L.: Rast moci ústavných súdov - limity a úskalia. In: JERMANOVÁ, H. - MASOPUST, Z. (eds.): Metamorfózy práva ve strědní Evropě. Praha: Ústav státu a práva, 2008, s. 191 - 205. ISBN 978-80-7380-149-6.

31. OROSZ, L.: Rekodifikácia volebného zákonodarstva (I.). Justičná revue, roč. 63, č. 10 (2011), s. 1219 - 1233.

32. OROSZ, L. - SVÁK, J. - BALOG, B.: Základy teórie konštitucionalizmu. Bratislava: EUROKÓDEX, 2011, s. 544. ISBN 978-80-89447-54-1.

33. OROSZ, L.: Ústavný súd Slovenskej republiky ako manufaktúra na ústavné st’ažnosti. In.: Ochrana l'udských práv a základných slobôd ústavnými súdmi a medzinárodnými súdnymi orgánmi - III. ústavné dni. Zborník príspevkov z medzinárodnej vedeckej konferencie. Košice: 23. september 2014. Košice: UPJŠ, 2014, s. 218 - 233. ISBN 978-808152-207-9.

34. OROSZ, L.: O aktuálnych problémoch pri ustanovovaní sudcov ústavných súdov (príčiny a dôsledky). In: CVRČEK, F. - JERMANOVÁ, H. (eds.).: Metamorfózy práva ve střední Evropě V. Překrásny nový svět nebo ostrov ? Plzeň: Aleš Čeněk, 2016, s. 69 - 8. ISBN 978-80-7380-636-1.

35. Stanovisko k štvrtej novele Základného zákona Mad’arska, prijaté Benátskou komisiou na jej 95. plenárnom zasadnutí, 14.-15.júna 2013, CDL-AD (2013)012. https://www.ustavnysud.sk/analyticke-prehlady/stanoviska-benatskej-komisie.

36. Stanovisko k novele organického zákona o ústavnom súde a k novele zákona o konaní pred ústavným súdom, prijaté Benátskou komisiou na jej 107. plenárnom zasadnutí, 10.11. júna 2016, CDL-AD (2016)017. https://www.ustavnysud.sk/analytickeprehlady/stanoviska-benatskej-komisie.

37. Stanovisko k novele zákona o Ústavnom tribunáli Pol'skej republiky z 25. júna 2015, prijaté Benátskou komisiou na jej 106. plenárnom zasadnutí, 11.-12. marca 2016, CDL$\mathrm{AD}(2016) 010 . \quad$ https://www.ustavnysud.sk/analyticke-prehlady/stanoviska-benatskejkomisie.

38. Stanovisko k otázkam týkajúcim sa menovania sudcov Ústavného súdu Slovenskej republike, prijaté Benátskou komisiou na jej 110. plenárnom zasadnutí 13. marca 2017, CDL-AD (2017)001 č. 877/2017. https://www.ustavnysud.sk/analytickeprehlady/stanoviska-benatskej-komisie.

39. SUCHÁNEK, R.: Ústavní soudnictví ve státech střední a východní Evropy. In: PAVLÍČEK, V. a kol.: Transformace ústavních systémů zemí střední a východní Evropy. I. část. Praha: Univerzita Karlova, 1999, s. 50 - 87.

40. ŠEVČÍK, V.: Ústavní soudníctví v praxi. Bulletin advokacie 1999, č. 11, s. 14 -23. 
41. Minister spravodlivosti SR G. Gál predstavil navrhované zmeny pri vol'be sudcov ústavného súdu

https://www.justice.gov.sk/Stranky/aktualitadetail.aspx?announcementID=2342.

42. VYHNÁNEK, L: Jak vybírat soudce ? Hledání modelu pro mladé demokracie. In. In: Výber ústavných sudcov. Prístupy k spravodlivosti. Bariéry a východiská 13. Banská Bystrica: VIA IURIS, 2018, s. 27 - 31. ISBN 978-80-89805-01-3.

\section{KONTAKTNÉ ÚDAJE AUTORA}

doc. JUDr. Ladislav OROSZ, CSc.

docent Katedry ústavného a správneho práva

Právnická fakulta UPJŠ v Košiciach

Kováčska 26 Košice

telefon: 0908679490

e-mail: ladislav.orosz@upjs.sk 